\title{
Comparing the Soviet and Chinese Famines: Their Perpetrators, Actors, and Victims
}

\author{
Lucien Bianco \\ L'École des hautes études en sciences sociales
}

\begin{abstract}
The Soviet (1931-33) and Chinese (1958-62) famines were man-made catastrophes that occurred in underdeveloped states with growing populations during peacetime and affected traditional surplus areas. Both are marked by overly ambitious industrialization strategies at the expense of the rural economy in which central authorities failed to lower grain quotas once famine broke out and even increased them. The famines also had differences, notably regarding the nationality or ethnic question, which played a key role in Ukraine and was present in the Kazakh famine, but was absent in the Chinese famine. Also, Chinese Communist Party leaders, notwithstanding the cruelty of their policies, were much better disposed towards peasants than were the Soviet Bolsheviks. One cannot ascribe murderous intent on Mao's part, but rather an incoherency of policy and unwillingness to recognize and correct his errors.
\end{abstract}

Keywords: Famine, Revolution, Soviet Union, China, Ukraine, National Minorities

$\mathrm{T}$

he two greatest famines of the twentieth century (1931-33 and 195862) were, as Andrea Graziosi has written, man-made. They occurred in peacetime in the absence of locust or other plagues, and in countries equipped with means of transportation sufficient to convey food to areas short of grain. They struck traditional surplus areas, such as Sichuan Province-“"heaven's granary" - in China or fertile Ukraine, especially hard. ${ }^{1}$ Sichuan and Ukraine lost a much larger proportion of their populations than the approximately five percent of Chinese and Soviet citizens who died from hunger. In the hardest hit areas, but elsewhere as well, each famine brought about notable regression in the quality of life.

Let us analyze first the evident affinities between these famines and then turn to a discussion of their differences and the responses of the perpetrators and their victims.

1 Thankful northern Ukrainian peasants marveled at the fertile chernozem: "If you drive a dry stake into the earth, it'll turn green" (Sokoloff). 


\section{SIMILARITIES}

1. Both famines arose in countries beset with similar problems. In 1949 China's GDP per capita was among the lowest in the world and remained so until the eve of the fateful Great Leap Forward (Wemheuer 2014, 27, 270). Walter Mallory famously described China as the "land of famine," a characteristic that Felix Wemheuer extends to Russia and the Soviet Union in the nineteenth and twentieth centuries (Wemheuer 2014, 26). Though less poor than China, the Russian Empire experienced famines accompanied by violence in 1891, as did Russia and Ukraine in 1921-22, followed by residual local famines in 1924 and 1926. Even bloodier had been the 187679 famine in China, which was followed by recurring famines during the Republican era in 1920-21, 1928-30, and 1943. Both revolutionary regimes thus inherited a stupendous and challenging burden, and both faced conditions of widespread poverty and underdevelopment. The latter was more pronounced in China, which was also, in the language of the time, "overpopulated."

Before the famines, the beginnings of a demographic transition had brought about a rapid increase in the populations of both countries, especially China's. A generation later, mortality from infectious disease had been significantly reduced throughout the world. The population increase was hastened by policies-especially in China from 1949 to 1958-that quickly decreased death rates. In 1950, for instance, nine percent of those who contracted measles in China died; by 1958 the proportion was down to two percent. During that initial phase of the demographic transition, a rapidly decreasing death rate combined with a continuously high birth rate to maintain the annual growth rate at 2-2.5 percent in the years $1955-57$ preceding the Chinese famine (Banister 46, 56, 352). A generation earlier, in the USSR both birth and death rates were much higher, resulting in a more moderate but still high annual growth rate-around two percent between 1924 (after the lasting crisis brought about by the First World War, the civil war, and the 1921-22 famine) and 1928, on the eve of Stalin's Great Turn. In 1928 Stalin needed to feed 41 million more people than Tsar Nicholas did at the time of the 1897 census, while relying on an agricultural output that had barely increased (Blum 90-97; Nove 12, 310).

Swift urban growth increased the number of people who consumed grain they did not produce. Between 1928 and 1933 the Soviet urban population grew from 26 million to 38 million, and the non-agricultural 
work force, from 12 million to 20 million. In China, the urban population grew at an even faster rate: by eight percent in 1957 and fifteen percent in 1959. By 1959 the urban population had increased by 16.5 million, from 107.2 million to 123.7 million. It grew even more the following year. ${ }^{2}$

2. In both countries, a similar development strategy, namely, accelerated industrialization at the expense of the rural economy and society, brought about famine. Evgenii Preobrazhenskii had recommended this strategy during the famous 1925 controversy in which he opposed Bukharin. Stalin implemented it from 1928 on and with even more ambitious goals and resolute inhumanity. ${ }^{3}$ While no statement recalling Preobrazhenskii's program of accomplishing "primitive accumulation" at the expense of the peasantry was ever uttered in China, Stalin's strategy was faithfully imitated there. The turns in 1928 and 1958 in these countries to radical, overambitious policies sharpened already existing conflicts between the state and the peasants. Acute during the Russian Civil War, such conflicts had softened but not disappeared after Lenin launched the New Economic Policy. As early as 1953 in China, the writer and rural reformer Liang Shuming, who had made a famous visit to Mao in Yan'an, harshly criticized the differences in the living standards of workers and peasants. The former lived "in the ninth heaven," the latter "in the ninth hell," according to Liang Shuming. After the "unified purchase and sale of grain" was promulgated that same year, the state extracted at a very low price a share of grain production that was much larger than what farmers were willing to cede. From then on the authorities and the peasants struggled over the disposal of the so-called agricultural surplus. Supply crises recurred as the government sought to feed an expanding urban population and, at the same time, export agricultural products in order to finance machinery imports.

Recurring disagreements over agricultural surplus suddenly became more threatening on the eve of the fateful Great Leap Forward. During the 1957 Socialist Education campaign, which amounted to a rural counterpart of the Anti-Rightist campaign targeting urban intellectuals, peasants who complained about the bitterness of their lives became politically suspect and their ideological shortcomings were deemed the root of their "false" claims of grain shortages. This "politicization of hunger" (Wemheuer) would have tragic consequences during the famine, when starving villagers

\footnotetext{
${ }^{2}$ For the Soviet Union, see Davies and Wheatcroft 434; Wheatcroft 22-24. For China, see Banister 330-31; Lardy 369; Yang 320, 341, 443-44.

3 That important controversy is detailed in Cohen, ch. 6; and Nove, ch. 5.
} 
no longer dared to complain because it had become taboo to mention hunger. ${ }^{4}$

Famine broke out in each country (from 1929 and from 1958 onward) when agrarian policies were suddenly radicalized to an extreme, unforeseen extent. The setting of overambitious goals to be achieved at utmost speed amounted to what Andrea Graziosi has rightly labelled "miracleism." In order to reach these goals, the state extracted from the peasants what Stalin called "tribute" - grain-requisition quotas far beyond their capacity to produce. Consequently the peasant producers, who were by far the main victims of the famines, starved. The nature and practices of the revolutionary regimes changed grain collection into ruthless extortion. The hierarchical nature of both the Soviet and Chinese Communist Parties precluded any questioning of the dictators' ukases and incited regional and local authorities to rip the shirts from their constituents' backs, for it was safer to err leftward than risk being labelled a rightist.

3. Excessive grain collections not only persisted after famines had begun, but increased and reached deadly levels. In China the worst famine years (1959 and 1960) saw the highest procurement rates of the entire Mao era (Wemheuer 2014, 45-46). Those who could not fulfill targets were labeled rightists and punished as such. Penalties had been even more severe for numerous Ukrainian villages and kolkhozes "blacklisted" for nonfulfillment of the grain-collection quotas. Party secretaries of defaulting units were themselves quite often deposed, even arrested, or worse (Davies and Wheatcroft 173-98). Brutal means of extortion were applied in both countries. Police and armed detachments seized the farmers' last reserves, including seeds. During searches for hidden grain, steel shafts were used in Ukraine in 1932, and walls were torn wide open in Tibet from 1961 to 1963 (Sokoloff 306; and Becker 238).

Rather than providing relief to the starving, Soviet authorities found it expedient to strip them of the last remnants of their gold and silver-not gold coins, which they were supposed to have delivered to the state treasury long before, but family heirlooms such as icons, earrings, wedding bands, silver teapots, and so on. As a rule, the Torgsin stores (well-supplied for foreigners, who were supposed to pay with foreign currency) were confined to the big cities. In December 1932 Torgsin stores were suddenly opened in some of the by then desolate Ukrainian raion centres. They

4 Wemheuer 2011, 107-16, and 2014, 93-110. This entire paragraph is based on Bianco 2014, 121-37, 163-73, 189-93, 202-210, and Wemheuer 2014, ch. 3. 
offered plenty of wonderful things, especially food, in exchange for gold or silver. Trading a gold medallion could help a family survive but also raise the suspicions of a village chairman, who would then order a thorough search of the home for concealed gold coins (Dolot 177-88).

In both countries the administrative units of locales (rural soviets, people's communes) and even whole districts competed in extracting grain. Many feared demotion or arrest; others hoped to be promoted by showing good extraction results; and still others shared the feelings of those county leaders in southeastern Henan Province who asserted: "Better to have a few hundred dead than to lose honour," in other words, to lag behind neighbours (Becker 167). ${ }^{5}$

Whether motivated by fear or ambition or a combination of both, a majority of local leaders were induced to hide insufficient results-in other words, to lie and claim higher production than was actually achieved. The accumulation of successive lies at each level of the administrative hierarchy resulted in seriously distorted national figures. Grain-collection quotas therefore relied on highly overestimated harvests, more so in China than in the Soviet Union. Central leaders were slow in discovering this reality and were therefore very late in reducing collection quotas. They even ended up not only reducing quotas but giving back part of the collected grain to the starving producers. In 1959 in China, the state collected 67.4 million tonnes of grain from peasant producers and later gave back almost 20 million tonnes. ${ }^{6}$

Official aid to famine victims was both too little and came too late, more so in Ukraine than in China.

4. In both countries, grain rations for industrial workers were larger than those for peasant producers, and much larger for urban dwellers than for villagers. One reason for this was the regimes' reluctance to acknowledge the existence of famine. Whereas Lenin did not hide the 192122 famine and welcomed foreign aid, Stalin, in both 1932-33 and 1946-47 in Ukraine, and Mao, in 1958-62, tried to hide widespread famine as best as they could. ${ }^{7}$

${ }^{5}$ In the spring of 1960, as famine raged in Gansu Province, Dingxi Prefecture, Party Committee Secretary Dou Minghai likewise declared: "I still prefer that people die; we may not request grain from the State" (Yang 296).

${ }^{6}$ According to Ash $(970,973), 19.8$ million tonnes.

${ }^{7}$ Even in 1921, owing to pressure from the Gosplan and other Communist leaders, harvest estimates almost doubled, in turn increasing procurement quotas and aggravating hunger. See Thévenin 334. 
Local cadres and physicians were prevented from recording the cause of hunger-related deaths. Not far from Kyiv, a rural soviet secretary had to rewrite his report on deaths from hunger and assign every death, including of one-year-old infants, to old age. In China, when the Jiabiangou camp near the Gobi Desert was closed in late 1960, a physician prisoner had to remain there for another six months, the time required to fabricate every imaginable disease for each death from hunger (Sokoloff 301; and Yang 2010, 368-69).

By denying famine, both countries deprived themselves of international assistance. They furthermore continued exporting grain while grain producers were dying from hunger: exports from the Soviet Union continued in the 1930s, and from China with no interruption but on a reduced scale until 1960. Wemheuer has calculated that the Chinese grain exports of 1960 could have saved more than five million lives, and that the Soviet grain exports of 1932-33 could have fed all of the victims of the famine. In other words, "exports were an important contributing factor" to both famines (Wemheuer 2014, 247).

As Wemheuer (particularly in 2014, ch. 2 and 4) has explained, the regime had its survival in mind when it decided to feed city dwellers first, better, and at the expense of villagers. Food riots are more dangerous in cities, as was dramatically evidenced in Petrograd in February 1917. The rapid growth of the urban population, combined with exports, made it more and more difficult to feed those living on state rations. The Soviet internal passport system was established in December 1932 in the midst of the famine to prevent mass exodus from the countryside; while Chinese leaders imposed the hukou system, which forbade people born in a village to migrate and live in any city, before the famine occurred. Cities such as Beijing, Shanghai, Tianjin, and Shenyang in the industrialized northeast were given absolute priority as recipients of grain distribution. In the Soviet Union rules had been even more elaborate and constraining. Category A cities such as Moscow, Leningrad, and, in starving Ukraine, Kharkiv, Dnipropetrovsk and cities in the industrialized Donbas received supplies through the centralized grain collection. Category B cities-eighty when the list was established in 1930-received some food from the centralized resources, but they had to supplement it with local grain collections. Category C cities were forced to rely entirely on local resources. Even so, they remained privileged compared to their surrounding countryside, which was supposed to feed them as well as the more distant A or B cities first, then to save grain as seed, and only then to consume what food remained or to starve. It is Wemheuer's contention $(2014,253)$, which I share, that protecting the cities was such a priority for both regimes that they fed them by starving the countryside. Officially classless societies were 
in fact "dual societies": those peasants who had failed to realize this earlier learned the bloody lesson during the famine that they were second-class citizens.

\section{DIFFERENCES}

The differences between the famines are much less significant than the similarities, which I have not nearly exhausted in the above remarks. We will encounter quite a few more analogies, even lineage, between the comportments of actors and victims sketched in the last part of this contribution.

Let us now proceed from the less to the more important differences.

1. Among the less important are those that relate to agricultural work. In Ukraine, superficial ploughing decreased yields. ${ }^{8}$ One can expect such shortcomings when horses are lacking and reluctant kolkhoz members botch collective work. In China the opposite was done, with even more catastrophic results. To be sure, deep ploughing was tried in the Soviet Union first, but Mao here, as elsewhere, meant to outmatch his model: land was often dug up to one meter and sometimes four and even five meters deep. In Guizhou Province trenches were so deep that farmers needed to rope up in order to avoid drowning. In impoverished Anhui Province some fields remained unproductive for several years as a result of deep ploughing (Becker 107, 113-114; Yang 77, 119, 259-60).

In Ukraine yields suffered as well from an excessive increase in cultivated land. In normal years the proportion of fallow had been smaller in Ukraine than in the rest of the Soviet Union. In 1931 it became almost nonexistent, and its absence exhausted the soil (Davies and Wheatcroft 436-37, 452). Again, this was a natural response to food deficiencies-quite the opposite of what was done in China, where sowed areas significantly decreased in 1959: the 1958 harvest was reputed to have been so fantastic that the Chinese would not have use for such mountains of grain.

2. Next are the differences that relate to the implanting of the Chinese Communist Party (CCP) in the countryside and the new institutions the CCP devised. The embedding of the CCP in the countryside was more widespread and much deeper than that of the Bolsheviks. There was no

8 "In many places, ... [kolkhozniks] did not plough, but merely scratched the land on the surface" (Ukrainian leader Khataevich report, 16 August 1932, quoted in Davies and Wheatcroft 108). Not only ploughing, but sowing and harvesting as well were often carried out in a slipshod manner (Davies and Wheatcroft 438). 
need in China to send to the countryside anything like the infamous "Twenty-Five Thousanders"-workers and other city activists dispatched to the villages in the winter of 1929 in order to promote, or rather impose, Soviet collectivization and dekulakization. ${ }^{9}$ Yet even in China the sway of the centre over villages remained uneven at best. Local cadres proved quite free to choose among a wide variety of means in order to meet unrealistic quotas. The supposed empathy of national leaders towards the "peasant masses" proved to be less effective than is often assumed. During the spring of 1959 Mao pretended to understand peasants who hid their grain in order to "defend their class interests." The following two years gave ample proof that, in spite of their rural origins, Mao and most other Chinese leaders did not understand peasants, though they misunderstood them less than Stalin did. More importantly, the CCP leaders were much better disposed towards peasants than the Bolsheviks had been.

People's communes and collective canteens were Chinese novelties (and failures) with no equivalent in the Soviet Union. They were introduced not only for social but also for economic reasons as means towards a goal, namely industrialization, which China's leaders hoped to accomplish by exploiting the huge reservoir of rural manpower. Commune leaders had absolute power over their 15,000 to 25,000 members, moving them from task to task and separating husbands from wives and parents from children. Canteens wasted food as a result of sloppy management, privileges, and corruption. According to the foremost student of the Chinese famine, canteens were responsible for one-third of the total number of deaths (see Yang 191).

3. The link between famine and ethnic groups/nationalities is essential in the Soviet Union, but unimportant in China. To be sure, both large countries were multi-ethnic empires. However, the Han Chinese represented not less than ninety-four percent of the enormous Chinese population in the 1953 census, whereas Russians made up only fifty-three percent of the Soviet population surveyed in 1926 (Wemheuer 157-58). The proportional distribution of the population according to ethnicity was evident among the dead from hunger in China (where Han Chinese possibly made up more than ninety-four percent of the victims), but not at all in the Soviet Union. As Graziosi has pointed out, some eighty percent of the Soviet

\footnotetext{
${ }^{9}$ In a Ukrainian village some hundred miles south of Kyiv, villagers used to call them simply tysiachnyky 'thousanders,' and their hated chief "the thousander." The rest of the thousanders were even more despised for their total ignorance of agriculture. See Dolot 4, 12.
} 
famine victims were members of ethnic minorities, mostly Ukrainians and Kazakhs. Whereas Kazakhs did not die so much from purposeful action as from the consequences of irresponsible, brutally implemented policies and indifference to the victims' fates, this was not the case for most of the Ukrainian peasants who died between October 1932 and June 1933. Like Kazakh nomad breeders in 1931, the Ukrainian peasants who died during the spring of 1932 were victims of foolish, cruelly imposed policies. Beginning in the fall of 1932, Stalin's fear of "losing" Ukraine and the link he had long established between the "national" and "peasant" questions probably incited him to use hunger against potentially separatist Ukrainian peasants. ${ }^{10}$ In other words, the significance of the famine became utterly different, justifying the label "Holodomor," and remained so when it became bloodiest from the early spring of 1933. Murderous measures targeting Ukrainian peasants were paralleled by repressive policies against the urban Ukrainian elites, which continued into 1934, after the famine had abated.11

In China the famine was more severe in mostly Han-populated provinces such as Anhui and Henan than among non-Han living in the periphery. To be sure, "minority" people also died from hunger in Inner Mongolia, Qinghai, Xinjiang, and Tibet. In the latter "autonomous" region the policy of "indigenization," adapted from the Soviet korenizatsiia, became less tolerant after the famine, largely as a consequence of uprisings provoked by hunger in Qinghai in 1958, which preceded the uprising in

${ }^{10}$ I say "probably" because of Davies and Wheatcroft's objections in their excellent studies. The question has since been hotly debated in scholarly journals, especially in Europe-Asia Studies 57-60 (2005-08). I explained in Bianco 2014, 234, why I found Graziosi's argumentation more convincing (see his contribution "The Uses of Hunger: Stalin's Solution of the Peasant and National Question in Soviet Ukraine, 1932 to 1933" in Curran, Luciuk, and Newby 223-60). I have since been further convinced by Graziosi's lecture "Stalin and Hunger as a Nation-Destroying Tool" (www.youtube.com/watch?v=6bXzQr2Ba5E), which concluded the conference Communism and Hunger: The Ukrainian, Chinese, Kazakh, and Soviet Famines in Comparative Perspective, Toronto, 27 September 2014, as well as by his introduction in Graziosi 2013.

${ }^{11}$ See, among others, the dispatches Sergio Gradenigo, the Italian consul general in Kharkiv, sent to Rome on 3 May, 15 May, and 7 June 1934, in Graziosi 2013, 253-59, 263. Gradenigo had already alerted the Italian government about anti-Ukrainian policies in his dispatches of 31 May and 22 June 1933 (Graziosi 2013, 179-86, 197 200). He wrote as early as the end of May 1933 that "there is no doubt that the hunger is first of all the result of a famine organized on purpose to teach the peasants a lesson" (Graziosi 2013, 179). 
Tibet in 1959 (see Wemheuer 2014, 168-70, 191). In contrast, Stalin intentionally altered the korenizatsiia, and actually ended it for the Ukrainians living in the RSFSR. In China the geography of the famine seems to have corresponded more to economic factors, such as those Garnaut analyzed, than to the identities, personalities, and choices of provincial leaders, and not at all to national considerations (see Garnaut 315-48).

4. The evolution of the famine proved more erratic in China, and the mortality peak lasted longer there. In the Soviet Union, as Graziosi has pointed out, there were different famines, with the Kazakh famine (in 1930 and especially 1931) amounting to a first and different famine. From the spring of 1932 onward hunger struck in Ukraine and other southern areas, and an unyielding escalation then followed, first during the summer of 1932 and then during the autumn and winter. The latter was by far the more fateful. The acme of the crisis in Ukraine lasted from two to five months, beginning in early or late March 1933.12

In China the famine lasted four years, from 1958 to 1962. It began in the fall of 1958, was fought with unequal success from November 1958 to July 1959, and then galloped from the fall of 1959 onward. High death rates continued not over a few months but for two full years (1960 and 1961). The acme of the crisis-the mortality peak-lasted a full year, from the winter of 1959 to late 1960. In order to suggest the fateful consequences of Mao's response to Peng Dehuai's criticisms at the Lushan Plenum (JulyAugust 1959), I quote a recent estimate of the number of "abnormal deaths," meaning deaths from hunger (Li 46-52).

\begin{tabular}{|rr|}
\hline Year & Deaths \\
\hline 1958 & 921,000 \\
\hline 1959 & $4,819,000$ \\
\hline 1960 & $17,002,000$ \\
\hline 1961 & $8,476,000$ \\
\hline 1962 & $3,350,000$ \\
\hline Total & $34,568,000$ \\
\hline
\end{tabular}

I do not claim that these estimates are more reliable than those various scholars have made (they vary from 15 million to 46 million deaths

12 Three months, from early April to late June as Andrea Graziosi wrote; two months, from late March to late May in some parts of southern Ukraine (see Dolot 197,230 ); or even five months, from March to July in more afflicted areas. 
altogether), but few of them have attempted to do a year-by-year calculation. The total number of roughly 34.6 million dead from hunger mentioned here is in the range of the less unreliable estimates at our disposal. ${ }^{13}$ According to Li, almost half (17 million) died in 1960 and more than half of the rest in 1961, namely, 8.5 million, for a total of nearly 25.5 million during the two worst years, that is, 73.9 percent, closer to threefourths than to two-thirds, of the total number of deaths. Again, more than half of the remaining deaths occurred in a single year, namely, 4.8 million in 1959. We can assume that most of these deaths occurred during the last four months of the year, when the anti-rightist-opportunist campaign raged. The rest were distributed between the first and last years of the famine: 921,000 deaths in 1958 and 3.35 million deaths in 1962.

This long-lasting crisis was the result not only of the leadership's blunders and the time (and lives) it wasted before it implemented the necessary remedies. It also reflects the objective conditions prevailing in China before the famine: China had less room to manoeuvre than the Soviet Union did. Stalin and his accomplices were at least as, if not more, responsible than Mao for the famine-inducing policies and their results. Why was the impact of the famine greater in China? Because under the socalled normal conditions that prevailed before the famine broke out, the inhabitants of that "overpopulated" country consumed the barest minimum of calories needed to survive in normal times. Only $307 \mathrm{~kg}$ of grain per person were available in 1956, the best year since the People's Republic had been established, and this amount was not reached again until 1975, the year before Mao's death, when it was slightly surpassed-308 kg. On the eve of the Soviet famines the USSR produced almost $500 \mathrm{~kg}$ (488 kg in 1928) of grain for each person. To be sure, horses consumed a part of the grain, but horses could be killed and eaten once hunger struck. Livestock,

13 According to the Chinese demographer Cao Shuji ("1959-61 nian Zhongguo de renkou siwang jiqi chengyin" [The Death Rate of China's Population and Its Contributing Factors from 1959 to 1961], Zhongguo renkou kexue [Chinese Demography] 1 [2005], 14-28), there were 32.5 million deaths. Yang Jisheng has proposed there were 36 million deaths. He has offered (in Yang 429-30) his own year-by-year distribution but has readily admitted that it is based on much underestimated provincial data. Out of a total of 20.98 million unnatural deaths, 11.09 million, or slightly over half, occurred in 1960, a proportion rather similar to that arrived at by Li. Contrary to the latter, Yang counted more deaths in 1959 (4.75 million) than in 1961 (3 million) and much more in 1958 (1.72 million) than in 1962 $(420,000)$. Both authors nevertheless agree that most of the deaths occurred from 1959 to 1961. 
alive or dead, provided Soviet people with meat or milk to a degree never available in China. The private plots that were abolished during the Great Leap Forward because of ideological blunders were tiny compared to the average plots in the Soviet Union, both before the Great Leap Forward and once they were re-established. The different sizes of the Soviet and Chinese private plots did not result from a more ardent collectivizing impulse among Chinese leaders: they merely reflected the person-to-land ratio.

5. Finally and importantly, there were differences in degrees. Both famines, regimes, and dictators shared characteristics to varying degrees. Stalin was crueler than Mao, and so was his regime toward starving people. In the preceding section I suggested that objective conditions made the Chinese famine more devastating, but was it really bloodier? Both famines killed about five percent of their countries' total populations. But if we subtract the millions of Ukrainian peasants killed intentionally during the winter of 1932 and the spring of 1933, the Soviet famines per se were much less lethal than the Chinese one. Descriptions of the relationships between the Soviet authorities and the starving peasants, especially the Ukrainian peasants, often give the impression that there was a state of war between the regime and the peasantry. In China we rarely have that sense. Chinese peasants may have suffered as much and died in even greater numbers, but the cruelties committed were less systematic. Some-too many-rural cadres turned to killing or torturing farmers once they saw no other means of reaching the impossible targets that were imposed. This occurred in the Soviet Union as well, among other forms of cruelty dictated from above. A comparison of grain exports is another area where the differences are a matter of degree. In the Soviet Union, they were reduced but never interrupted during the famine. In China, they were ended much too late but were at last replaced by imports.

If Stalin was the crueler despot, Mao was more inconsistent, more prone to irresponsible, even foolish policies. Especially after the Great Leap Forward of 1957-58, he at times behaved like the follower who aims to better his master and model. To be sure, Stalin was also disposed toward adventurist policies, but less than Mao was. If Soviet collectivization was too rash and too quick, Chinese communization (forced enrolment in people's communes) was accomplished with even more haste-in a few months for hundreds of millions of villagers. Chinese communes were bigger and more ambitious than kolkhozes, or even sovkhozes. Khrushchev once made the somewhat ridiculous prediction that the Soviet Union would achieve communism by 1980 . In China in 1958, however, a mid-level leader in Hubei Province declared that the communist era was scheduled for 8 November of the same year, the day after the celebration of the forty-first anniversary of the October Revolution (Becker 157). 
As indicated above, lies are another characteristic shared to different degrees. For a student of Soviet Communism, it is difficult to conceive of anyone surpassing the magnitude or impudence of the lies of Stalin's era. Graziosi has noted the qualitative change in official lies at the time, and a famine that officially never existed was a consequence thereof. Did not Stalin assert in a speech not long after the famine had abated that "Life has become happier, comrades" (Graziosi 43)? And yet, I claim the crown for China, especially on the eve of the famine, for claiming the highest yields achieved anywhere at any time in human history in a single country (China) during a single year (1958). According to provincial reports, the 1958 harvest in China amounted to 450 million tonnes, more than twice the 195 million tonnes harvested in 1957. Mao singlehandedly reduced it to 375 million tonnes, which instantly became the official truth. On this basis, he set the production target for 1959 at 525 million tonnes, and he further reduced the cultivated area by ten percent.

The leadership began worrying about a thorny issue: what to do with a rice and wheat surplus. Mao advised peasants to devote only mornings to work, and afternoons, to the cultivation of their minds. More than a few Chinese leaders may have entertained doubts about the amount of a harvest almost twice that of the previous year (even after Mao's reduction, the annual increase still surpassed ninety-two percent). Modest grain collections seemed to belie such miraculous harvests, even though these leaders could rightly suspect that peasants and local cadres were hiding part of the crop. Yet, none ever asked: "What if the increase in grain harvested this year (1958) were thirty or fifty percent instead of ninety-two percent?" In reality the increase was less than 1.4 percent above the 1957 harvest of 195 million tonnes-197.6 million tonnes. Or they could have asked: "Might not yields in such and such counties have merely doubled rather than quadrupled?" Grain-procurement quotas were set on the basis of such miraculous yields. Once news of deaths from starvation reached the leadership, the quotas were "kindly" reduced. Yet these reduced quotas occasionally represented eighty percent of the actual production, more than enough to leave farmers starving to death. ${ }^{14}$

14 In 1959, for example, Guangshan County in Xinyang Prefecture, Henan Province, which produced 88.4 tonnes of grain that year, was assigned a procurement quota of 75.5 tonnes, which amounted to 31.5 percent of the officially declared harvest of 239 tonnes and over 85 percent of the real one. Because the authorities could extract "only" 62.5 tonnes-seventy percent of the actual crop-they launched a thoroughly brutal "anti-concealment campaign." During that same year and in the 


\section{RESPONSES TO FAMINE}

1. The Actors. Above, we have just begun to assess the responsibility of both dictators. The post-Lushan Conference phase propelled Mao into Stalin's vicinity on the podium of mass murderers. As a result of Mao's response to Peng Dehuai's criticism, the number of deaths may have increased threefold. Yet, even the post-Lushan escalation - from the fall of 1959 to the fall of 1960-evokes that of the summer 1932 in Ukraine, not the final escalation of the autumn and winter of 1932. It is true that Mao knew as early as October 1958 that people had died of hunger. Yet, on the whole, Stalin had access to more reliable statistics than Mao did and was therefore in a better position to grasp the scope of the famine. He was much less troubled than Mao by the growing number of starving peasants-not to mention those Ukrainians peasants he, in all probability, knowingly let die to prevent them from supporting a potential but nonexistent "separatist" Ukrainian opposition. While Chinese leaders did not deliberately let Tibetan or Uyghur peasants die from hunger, they refrained from distributing the grain contained in silos (Soviet leaders did the same, and we saw that they kept grain). Even at the worst time, in 1960, silos in the two neighbouring provinces of Henan and Anhui contained more than two million tonnes of grain, enough to prevent the million deaths in Xinyang Prefecture on the border between those provinces. By and large, however, one can ascribe no murderous intent to Mao, but rather an inability to recognize and correct his errors and even a dramatic incoherency on the part of someone wielding absolute power. By November 1960 Mao was said to be abstaining from meat, even to have lost several pounds, which did not prevent him from devoting the essential part of a meeting of the Political Bureau to the issue of Sino-Soviet relations (Li 360; Roux 676).

The central leaders in both Moscow and Beijing, who obeyed their dictators, share significant responsibility for the famines. Nonetheless, there are differences in degree. Once he had got rid of the "second Himalaya" (Bukharin), Stalin mostly kept around accomplices such as Molotov and Kaganovich, who were eager and ruthless in carrying out his orders. In China too, the central leaders were not true leaders insofar as they always obeyed Mao. Their harsh criticisms of Peng Dehuai in 1959

spring of 1960 Xinyang Prefecture lost more than one million of its 8.5 million inhabitants to the famine. This euphemistically called "Xinyang Incident" is the subject of Qiao's Xinyang shijian (The Xinyang Disaster). See also Yang 23-68. 
were all the glibber because they had not disagreed with him before Mao's outburst (Khlevniouk, ch. 1-2; Yang 367-77; Teiwes and Sun 212).

A few years later, in 1962, when the end of the famine enabled Mao to launch a counter-attack and enjoin his lieutenants "not to forget the class struggle," Deng Xiaoping hastened to remove every reference to the colour of the cat from his famous speech (Khlevniouk; and Teiwes 341). Together with President Liu Shaoqi, he nevertheless tried to soften the implementation of Mao's damaging directives and began promoting policies that would later-after Mao's death-prove to be efficacious. In 1962, the last year of the famine, Liu was one of the very few to express courageous, if tardy, criticism of the official, Maoist line, for which he would pay with his life during the Cultural Revolution.

The behaviour of regional leaders in Ukraine and the Kuban was more what we expect from officials in a totalitarian regime than what we see in Henan and Anhui. In June 1932, Ukrainian leaders begged for but were refused food assistance from Moscow. In July they proclaimed the wheatcollection quotas to be unachievable before agreeing that they were achievable. The very leaders who, behind the scenes, attempted to obtain for their regions a reduction of, even an exemption from, grain collection, publicly supported quotas they knew to be unachievable (Werth 124-25; Davies and Wheatcroft 150,152,193). Some even begged to be forgiven for their former "errors." They showed "activism and cowardice," concluded an Old Bolshevik in October 1932 after just completing a two-month mission to Kharkiv. That was not the case for those who remained steadfast, such as Kotov, a local secretary in the northern Caucasus, who was sentenced to ten years and then to death for having allotted an extra grain ration to every kolkhoz member (Davies and Wheatcroft 157, 177-78).

In China too, quite a few local cadres tried and shielded commune members, and some provincial leaders, especially those born in the province they administered, took care to save the population from hunger. Historian Chen Yixin has contrasted the fate of two neighbouring provinces, namely, Jiangxi and Anhui (Chen 197-225). In Jiangxi 180,000 people died from hunger, amounting to 1.06 percent of the provincial population. In Anhui more than six million people died, amounting to 18.37 percent of the population, which means that every fifth to sixth Anhui inhabitant starved to death. Chen takes care to analyze several other factors that contributed to such a blatant discrepancy. He nevertheless points out that Anhui's first CCP secretary was from Hunan, while the first secretary of Jiangxi and his three main lieutenants were all born in Jiangxi.

A slight difference from the Soviet Union is suggested here: at first glance, famine seems to have been especially murderous in the provinces led by so-called "leftist" or radical leaders, such as Zeng Xisheng in Anhui, 
Wu Zhipu in neighbouring Henan, and Li Jingquan in Sichuan. ${ }^{15}$ In the Soviet Union, excluding the special case of Kazakhstan, famine appears to have been most murderous in such traditional grain-exporting areas as Ukraine and the Kuban-even before the fall 1932 escalation-because they were expected to contribute more grain to the state than other areas. Among the three Chinese provinces just mentioned, only Sichuan had the reputation of being a "rice loft."

A province, however, is too large an area for determining what parts of China suffered most from hunger. A recent study by Garnaut (315-48) classifies only parts of Sichuan, Anhui, and Henan Provinces among those areas most affected by famine and adds parts of other provinces as well. In other words, one cannot simply attribute the famine's severity to the responsibility of radical leaders or careerists eager to please Chairman Mao. According to Garnaut, the bulk of grain consumed in the major cities appears to have been collected first from surrounding districts with grain surpluses, then from farther districts with surpluses, and even from least developed regions with a relatively developed transport infrastructure. 16

Those who committed the most widespread and savage acts of violence against starving peasants were grassroots Communist cadres. They were both actors and victims. Higher officials intensely pressured them to fulfill unattainable quotas, and when these local cadres failed to do so, they incurred not only political sanctions, such as demotion, exclusion from the Party, dismissal, and even arrest, but were often beaten, wounded, tortured, and even executed (Yang 61-68, 118; Thaxton 191, 193). Because they were the ones in direct contact with villagers and ordered to pressure them to meet impossible quotas, what is described here is less their own behaviour than that of the Chinese Communist regime on the whole.

15 Zeng Xisheng later came to regret his leftist excesses and sanctioned the experimentation of the "responsibility contract," a dangerous rightist move in Mao's eyes. For that very reason, Zeng was labelled a rightist in 1962 and was later (during the Cultural Revolution) beaten to death by Red Guards.

16 This single-sentence summary does not adequately reflect the sophistication of Garnaut's demographic and economic analysis (see especially Garnaut 320, 323, $326,331-32,336)$. I do not share every conclusion he drew from his analysis of the different age cohorts, do not think that we should blame only the radical leaders in Beijing, and was disappointed not to find southern Henan, which includes Xinyang Prefecture, among the most severely affected areas. That said, Garnaut's stimulating, ground-breaking article has led me to revise some of my views. 
Although the most abused among all actors, local cadres nonetheless survived hunger in a much larger proportion than the other villagers. The cadres ate in a special mess hall and received better and more food than other commune members. They did not eat as well as urban cadres, but they were occasionally invited to attend meetings in town, described as "health recovering work" (Gao 192; Thaxton 232-34; Dikötter 193). Some cadres tried to save commune members by concealing and redistributing part of the crops; more common was favouring a few peasants at the expense of the others. According to a principle already tested in the Soviet Gulag, some cadres chose to allocate so-called death rations-feeding healthier workers more and better while punishing the lazy, weak, or sick by diminishing the quantity of their food to the point of hastening their demise (Wemheuer 126; Dikötter 301-302; Yang 189-90).

Rural cadres did not refrain from punishing, hitting, or beatingoccasionally to death-anyone caught stealing any amount of food or hiding any of the harvest from a collective field. They also staged fake executions, committed real ones, and drowned recalcitrant collective workers. According to an archival report dated 1961, the methods of torture local cadres used in Wanxian District of eastern Sichuan Province included hanging people, forcing them to kneel on burning coals, piercing their mouths, clipping off their fingers, stitching their lips, pushing needles into their nipples, force-feeding them feces, and so on (Zhou 21). Perhaps as many as a million victims of the Chinese famine died not from hunger but from beatings, torture, or execution (Dikötter 304).

Though duly reported in local Communist archives, the Wanxian case may have been a ghastly exception rather than the rule. But what about the Soviet Union? China did not enact legislation like the famous 7 August 1932 Soviet decree that made the taking of even a handful of grain a crime punishable by death. The prohibition against cooking at home was an oftrepeated measure but not a legislative act. The murderous anti-Ukrainian policies that began in the fall of 1932, which resulted also in the deaths of many ethnic Ukrainian peasants living in the Kuban, had no equivalent in China. In the USSR, blacklisted families, kolkhozes, and larger communities were deprived of basic supplies, and they could no longer buy anything because the co-operatives were empty and not allowed to receive any supplies. Peasants could be deported en masse to the remote Soviet East and North. In China individuals and collective units could be singled out and punished, but such ad hoc measures never became as systematic and encompassing as the blacklists Kaganovich's commission introduced in November 1932.

When the flight of peasants from starving Ukraine or from Henan and Shandong into Heilongjiang Province became massive, local officials were 
ordered to stop, or, better, prevent, the flight. Severe measures were taken in Ukraine in January and February 1933, but in China too it became forbidden to sell tickets in train stations and at ferryboat docks. Roadblocks were erected in order to halt fleeing peasants. Troops did shoot at runaways who attempted to cross the Yangzi and reach Nanjing, yet the hunt for refugees from hunger was much less massive and murderous than in the Soviet Union. Ukrainians who reached Batumi from Odesa in order to exchange valuables for wheat and flour were forced to return, and those who could not pay for the return trip had to sell their boots or clothes for next to nothing (Graziosi 154). Some two thousand peasants were picked up every day in Kharkiv and deported the following night. There in the early spring of 1933, a crowd of 1,500 people waiting in front of a bakery for it to open were seized and goaded with sticks to the train station. From there they were transported to the countryside and abandoned. ${ }^{17}$ Dying peasants were often thrown into pits and buried there together with corpses even though they pleaded, as an unfortunate mother of three did, "Please do not bury us, we are still alive" (Klid and Motyl 199). The spring thaw of 1933 exposed the corpses of many peasants alongside many roads, in backyards, and in fields (Klid and Motyl 200; Dolot 180). By a railroad station somewhere in southern Ukraine, Miron Dolot saw "a heap of frozen human corpses like some discarded woodpile" in plain view (Dolot 187).

Once manpower had become too scarce because many indigenous farmers were dead and the survivors were too weak to work, tens of thousands of students and workers in Kharkiv were forcibly dispatched to the fields, where they proved unable to distinguish between food plants and weeds. Later on, especially in the northern Caucasus, the army colonized villages whose inhabitants had died of hunger or had been deported, replacing them with Russian soldiers or aborigines brought in from Siberia. ${ }^{18}$ Most of these operations were managed by the GPU, which was unusually efficient as the only Soviet organization able to provide (bad) food or secure train tickets for VIPs. ${ }^{19}$ Carelessness and waste were especially conspicuous in the agrarian sector, because kolkhoz members

17 See Ambassador Bernardo Attolico's 7 April 1933 dispatch from Moscow and Consul Sergio Gradenigo's 22 June and 10 July 1933 dispatches from Kharkiv in Graziosi 164, 194-95, 205-206.

18 See, among other sources, Gradenigo's dispatches from Kharkiv on 10 July, 20 July, and 5 August 1933 in Graziosi 202-203, 210-211, 215, 217; and Attolico's 11 July 1933 dispatch from Moscow in Graziosi 209.

${ }^{19}$ See Attolico's 20 March 1933 dispatch from Moscow in Graziosi 192. 
proved reluctant to work hard on land seized from them or to maintain the tractors of the machine-tractor stations (MTS) with care. ${ }^{20}$ We cannot therefore entirely overlook the (modest) responsibilities of the victims themselves in bringing about the famine.

2. The Victims. Almost all of the victims were peasants. Some survived or hastened their deaths by eating dead rats, leaves, wood, and any food substitute, such as, in China, "Guanyin earth," which could be neither digested nor evacuated (Dikötter 284). The farmers saw their only chance of survival in escaping to the cities. Even if they could not find food there, they might leave their children there in the hope that someone would take them in. In Kharkiv alone some 18,000 children were abandoned in this manner. Among these children (the famous besprizornye in the Soviet Union), some teenagers became surrogate mothers by taking care of their younger siblings and covering them at night with their own coats (Dolot 181; Klid and Motyl 137; Graziosi 121). There are accounts of other kind persons, such as the starving old woman who welcomed a stranger with the words "See that small chunk of bread on the table? Take it. You're young, you need it. I don't. It won't help me anyway. I am dying" (Klid and Motyl 217).

Such instances were rare, however. I shall henceforth quote or paraphrase in order to describe responses to awful conditions. Any moral censure of the following condemns whoever proclaims it, not the victims: "Everyone wanted to live [...].Who wants to go to the grave for anyone, even the person closest to you? Only a mother could do that for a child, and not always even then" (Klid and Motyl 205). A grandmother saved her three grandchildren, whom her daughter had tried to suffocate. The mother had "fired up the oven, put [her] children to sleep, and closed the damper [to the chimney].... She could no longer listen to... 'Mom, I want to eat'” (Klid and Motyl 178). Under the strain of hunger, some "lapsed into comas, or existed in a semicomatose, lethargic stupor" (Dolot 198). Others reacted differently. Desperate beggars "were no longer the modest, honorable small farmers they had been before.... they lost all semblance of self-control, becoming more like wild, hungry beasts in their search for food. They no longer distinguished friends from enemies and were ready to commit even murder for a mere scrap" (Dolot 205). In a single southern Ukrainian village, two

${ }^{20}$ See the dispatch from the Italian vice-consul in Novorossiisk on 18 April 1933 in Graziosi 169; Gradenigo's dispatch from Kharkiv on 15 August 1933 in Graziosi 216; and many other sources. 
brothers "were beaten to death and thrown into an abandoned well. It was rumored that they were killed by their neighbor for stealing a cooked meal from his house. Another boy was beaten to death for stealing strawberries from someone's garden. A young woman met with the same fate for stealing vegetables" (Dolot 155). After the opening of a Torgsin store in the neighbouring county town, "Wearing gold jewelry openly, or having a gold tooth, was flirting with death. Murders committed for a pair of earrings, or a ring, or whatever else was made of gold or looked like gold, soon became everyday occurrences.... Thieves armed with tongs would forcibly extract the teeth from those who had gold crowns" (Dolot 178).

Some people "became like madmen.... They suffered from hallucinations of food, of something to bite into and chew, to satisfy the gnawing pains of their empty stomachs. Intolerable cravings assaulted them; they were ready to sink their teeth into anything, even into their own hands and arms, or into the flesh of others" (Dolot 198). Another Ukrainian survivor recalled how her mother killed someone to protect her: "my mother asked me back in 1940 ... 'Do you remember the man who bit your leg during the Holodomor? You started shrieking with pain. I heard you, dashed out of the cabin, and grabbed him by the throat to protect you. I couldn't stop strangling him with my hands until the man died"' (Klid and Motyl 217). No less tragic were memories of a different kind: "mothers... sometimes lost their sanity and... smothered their own children and ate them.... [Ivan Ostapenko's] mother put a noose around his neck and tried to strangle him, but he was stronger than she was and managed to break her hold" (Klid and Motyl 207).

Cases of cannibalism are mentioned so often in so many sources or studies relating to both famines that I will summarize with a quotation and a dictum. The first is from the Ukrainian poet Vasyl' Barka: "Mothers with several children would kill the smaller ones and feed the older ones with cutlets made of their flesh. That saved them" (Klid and Motyl 310). One hopes that the traditional Chinese dictum "land of famine" was more often remembered than practiced in Anhui Province in 1960: "yi zhi er shi," which means "exchanging children (with those of equally starving neighbours) and eating them" (Becker 196-197). ${ }^{21}$

${ }^{21}$ Cannibalism and, less frequently, trade in human flesh are referred to in Becker 226; Dikötter 320-23; Yang 14, 41-42, 44-45, 134-35, 142-43, 278-79, 289, 302-304, 311; Zhou 59-71. For the Soviet Union, see, among many other sources, Davies and Wheatcroft 423; Dolot 198-200; seven dispatches dated 6 January to 15 August 1933 in Graziosi 144-45, 165, 185, 196, 208, 211, 213-14; Klid and Motyl 26, 113, 
Did the victims go farther and rebel? Not much, considering what they endured. "Starving populations seldom rebel during a peak of famine" (Wemheuer 2014, 66). Revolts were more widespread and larger in scale in the Soviet Union, especially in Ukraine, but even in Ukraine riots and revolts were less frequent in the spring of 1933 than they were in the spring of 1930, after collectivization and dekulakization reached their peak. In China there were more cases of grain plundering than true riots, and those riots that erupted during the famine did not exceed the scale of those caused by collectivization in 1955. As James Scott writes, "everyday forms of resistance" are prevalent in Communist dictatorships, which are prone to bloodily repress the least attempt at revolting (Scott 15). Arson, sabotage, vandalism, personal retributions, and almost universal shirking of work by Soviet kolkhozniks and Chinese communards were the everyday forms of resistance (Dikötter 226; Klid and Motyl 132, 358; Graziosi 145).

More common examples of disobedience were the survival strategies of the peasants, who under-reported, hid or buried grain, stole crops, pilfered collective stocks, and ate immature green crops at night, often with the complicity of local cadres. ${ }^{22}$ Most fanxingwei (acts of resistance) that Chinese historian Gao Wangling analyzed illustrate what he called the infinitely diverse ways of "extracting food from the tiger's mouth" - in other words, the means of surviving and most other daily forms of resistance (Gao 285). Let us beware of romanticizing what were often desperate ways of surviving, when hunger "forced everybody, at one point or another, to make grim moral compromises" (Dikötter 15). ${ }^{23}$

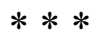

We may infer a few lessons about what existence becomes for humans confronted with horrific conditions and how they respond, and, more specifically, about Communism and cocksure revolutionaries who believe they know the definite truth about everything, especially the path and

116, 191, 197, 207, 217, 350-51, 353; Sokoloff 105; Werth and Berelowitch 498-99, $501,510,534$.

22 Resistance to requisitioning is documented, among many other sources, in Gradenigo's 15 August 1933 dispatch from Kharkiv in Graziosi 215-16. Various kinds of thefts are discussed in Gao Wangling. Thaxton ch. 6 is devoted to chi qing (eating green). "Eating green" in the USSR is documented in Werth and Berelowitch 540; and Dolot 156.

23 These compromises are discussed in Wemheuer 78-80, 149; Bianco 2005, ch. 19. 
ultimate destination of human history. This arrogant conviction may explain a bitter paradox: Chinese Communists were from the outset much closer to the peasants, much better disposed towards them, than the Bolsheviks had been, yet in the end, they were no less willing to sacrifice them on the altar of utopia. Nonetheless, although neither Stalin nor Mao ever acknowledged the 1931-1933 and 1958-1962 famines, they or their regimes drew some lessons from these catastrophes, if only because they constituted a threat to their power. Peasants were dealt with a bit less harshly afterwards, at least by Stalin's and Mao's successors. Birth control was reinstated as early as 1963 in China. But long overdue remedies cannot hide the awful "agricultural" performances of both revolutionary regimes. The Soviet Union became the world's largest importer of grain and agricultural products sixty years after tsarist Russia had been the world's largest exporter, and Deng Xiaoping rehabilitated-for a while-the living standard of most of China's peasants by resolutely opposing Maoist principles and policies.

\section{Works Cited}

Ash, Robert. "Squeezing the Peasants: Grain Extraction, Food Consumption and Rural Living Standards in Mao's China." The China Quarterly 188 (Dec. 2006): 959-98. Print.

Banister, Judith. China's Changing Population. Stanford, Calif.: Stanford UP, 1987. Print.

Becker, Jasper. La Grande Famine de Mao. Trans. Michel Pencréac'h. Paris: Dragorno, 1998. (Original English revision: Hungry Ghosts: China's Secret Famine. London: J. Murray, 1996). Print.

Bianco, Lucien. Jacqueries et révolution dans la Chine du xxe siècle. Paris: La Martinière, 2005. Print.

---. La récidive, révolution russe, révolution chinoise. Paris: Gallimard, 2014. Print.

Blum, Alain. Naître, vivre et mourir en URSS, 1994. Paris: Payot-Rivages, 2004. Print.

Chen, Yixin. "Under the Same Maoist Sky: Accounting for Death Discrepancies in Anhui and Jiangxi." Eating Bitterness: New Perspective on China's Great Leap Forward and Famine. Eds. Kimberly Ens Manning and Felix Wemheuer. Vancouver: University of British Columbia Press, 2011. 197-225. Print.

Cohen, Stephen F. Bukharin and the Bolshevik Revolution: A Political Biography, 1888-1938. New York: Oxford UP, 1980. Print.

Curran, Declan, Lubomyr Luciuk, and Andrew Newby. Famines in European Economic History: The Last Great European Famines Reconsidered. Abingdon, UK, and New York: Routledge, 2014. Print.

Davies, Robert W., and Stephen G. Wheatcroft. The Years of Hunger: Soviet Agriculture, 1931-1933. New York: Palgrave Macmillan, 2004. Print.

Dikötter, Frank. Mao's Great Famine: The History of China's Most Devastating Catastrophe, 1958-1962. London: Bloomsbury, 2010. Print. 
Dolot, Miron [Simon Starow]. Execution by Hunger: The Hidden Holocaust. New York: Norton, 1985. Print.

Gao, Hua. "Food Augmentation Methods and Food Substitutes During the Great Famines." Eating Bitterness: New Perspective on China's Great Leap Forward and Famine. Eds. Kimberly Ens Manning and Felix Wemheuer. Vancouver: University of British Columbia Press, 2011. 171-96. Print.

Gao, Wangling. "A Study of Chinese Peasant 'Counter-Action'." Eating Bitterness: New Perspective on China's Great Leap Forward and Famine. Eds. Kimberly Ens Manning and Felix Wemheuer. Vancouver: University of British Columbia Press, 2011. 272-94. Print.

Garnaut, Anthony. "The Geography of the Great Leap Famine." Modern China 40.3 (2014): 315-48. Print.

Graziosi, Andrea, ed., with the collaboration of Iryna Dmytrychyn. Lettres de Kharkov: La famine en Ukraine, 1932-1933. Trans. from Italian by Dominique Négrel and Anaïs Bokobza and from Ukrainian by Iryna Dmytrychyn. Lausanne: Les Editions Noir sur Blanc, 2013. Print.

Khlevniouk, Oleg. Le cercle du Kremlin: Staline et le Bureau politique dans les années 30: les jeux du pouvoir. Trans. from Russian by Pierre Forgues and Nicolas Werth. Paris: Seuil, 1996. Print.

Klid, Bohdan, and Alexander J. Motyl, comps. and eds. The Holodomor Reader: A Sourcebook on the Famine of 1932-1933 in Ukraine. Edmonton and Toronto: Canadian Institute of Ukrainian Studies Press, 2012. Print.

Lardy, Nicholas R. "The Chinese Economy under Stress, 1958-1965.” The Cambridge History of China. Vol. 14. The People's Republic, Part 1: The Emergence of Revolutionary China, 1949-1965. Eds. Roderick MacFarquhar and John K. Fairbank. Cambridge: Cambridge UP, 1987. 360-97. Print.

Li, Che. "Dajihuang niandai fei zhengchang siwang de ling yizhong jisuan." Yanhuang Chunqiu 7 (2012): 46-52. Print.

Li, Zhisui. The Private Life of Chairman Mao. Trans. Tai Hung-Chao. New York and Toronto: Random House, 1994. Print.

Mallory, Walter H. China: Land of Famine. New York: American Geographical Society, 1926. Print.

Nove, Alec. An Economic History of the USSR, 1917-1991. London: Penguin, 1992. Print.

Qiao Peihua. Xinyang shi jian. Hong Kong: Kai fang chu ban she, 2009. Print.

Roux, Alain. Le singe et le tigre: Mao, un destin chinois. Paris: Larousse, 2009. Print.

Scott, James C. "Everyday Forms of Resistance." Everyday Forms of Peasant Resistance. Ed. Forrest D. Colburn Armonk, N.Y.: M. E. Sharpe, 1989. 3-33. Print.

Sokoloff, Georges. 1933, l'année noire: Témoignages sur la famine en Ukraine. Paris: Albin Michel, 2000. Print.

Teiwes, Frederick C. Politics and Purges in China: Rectification and the Decline of Party Norms, 1950-1965. 2nd ed. New York: M. E. Sharpe, 1993. Print.

Teiwes, Frederick C., and Warren Sun. China's Road to Disaster: Mao, Central Politicians, and Provincial Leaders in the Unfolding of the Great Leap Forward, 1955-1959. Armonk, N.Y.: M.E. Sharpe, 1999. Print. 
Thaxton, Jr., Ralph A. Catastrophe and Contention in Rural China: Mao's Great Leap Forward Famine and the Origins of Righteous Resistance in Da Fo Village. New York: Cambridge UP, 2008. Print.

Thévenin, Etienne. “Les logiques à l'œuvre dans les famines soviétiques: L'exemple de l'Ukraine." Les logiques totalitaires en Europe. Ed. Stéphane Courtois. Paris: Rocher, 2006. 326-37. Print.

Wemheuer, Felix. Famine Politics in Maoist China and the Soviet Union. New Haven: Yale UP, 2014. Print.

---. "The Grain Problem Is an Ideological Problem: Discourses of Hunger in the 1957 Socialist Education Campaign." Eating Bitterness: New Perspectives on China's Great Leap Forward and Famine. Eds. Kimberly Ens Manning and Felix Wemheuer. Vancouver: University of British Columbia Press, 2011. 107-116. Print.

Werth, Nicolas. La terreur et le désarroi: Staline et son système. Paris: Perrin, 2007. Print.

Werth, Nicolas, and Alexis Berelowitch. L'État soviétique contre les paysans: Rapports secrets de la police politique (Tcheka, GPU, NKVD), 1918-1939. Paris: Tallandier, 2011. Print.

Wheatcroft, Stephen G. "Famines in Russia and China in Historical Perspective." Paper presented at the Seminar on Hunger, Nutrition, and Systems of Rationing under State Socialism (1917-2006), University of Vienna, 2008. Print.

Yang, Jisheng. Tombstone: The Great Chinese Famine, 1958-1962. New York: Farrar, Straus and Giroux, 2012. Print.

Yang, Xianhui. Le chant des martyrs dans les camps de la mort de la Chine de Mao. Paris: Balland, 2010. Print.

Zhou, Xun, ed. The Great Famine in China, 1958-1962: A Documentary History. New Haven: Yale UP, 2012. Print. 